AVERTING THE APOCALYPSE 



\section{AVERTING THE}

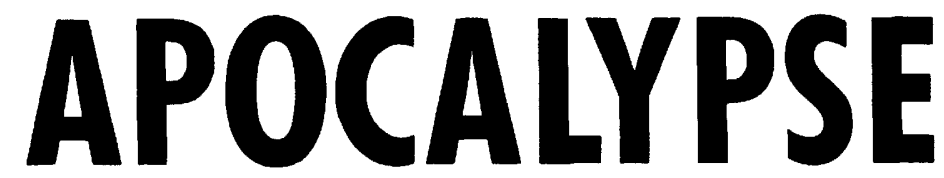

SOCIAL MOVEMENTS IN INDIA TODAY

Arthur Bonner 
(C) I 990 Duke University Press

All rights reserved

Printed in the United States of America

on acid-free paper $\infty$

Library of Congress Cataloguing-in-Publication

Data appear on the last printed page of this book.

Maps by Christopher L. Brest 